\title{
Manajemen Asuhan Keperawatan Jiwa Pada Tn. I Dengan Masalah Halusinasi Pendengaran: Studi Kasus
}

\section{Yuris Dawinda Waruwu}

\author{
jhuriswaruwu@gmail.com
}

\section{BAB I \\ PENDAHULUAN}

\subsection{Latar Belakang}

Skizofrenia berasal dari kata schizein (pecah-belah) dan phren (otak). Menurut Bleuler (1939, dalam Poegoeh, 2016) menyebutkan istilah skizofrenia yang secara tepat menonjolkan gejala utama dari gangguan ini seperti otak yang terpecah belah. Artinya, ada keretakan atau pemisahan antara proses pikir, respon-respon perasaan atau afektif dan perilaku. Skizofrenia merupakan sekelompok reaksi psikotik yang memengaruhi berbagai area fungsi individu, termasuk cara berpikir, berkomunikasi, menerima, menginterpretasikan realitas, merasakan dan menunjukkan emosi yang ditandai dengan pikiran kacau, waham, halusinasi, dan perilaku aneh (Pardede, Hasibuan, 2020).

Skizofrenia menimbulkan distorsi pikiran, distorsi persepsi, emosi, dan tingkah laku sehingga pasien dengan skizofrenia memiliki risiko lebih tinggi berperilaku agresif di mana perubahan perilaku secara dramatis terjadi dalam beberapa hari atau minggu. Hal inilah yang membuat perlu bantuan keluarga untuk merawat dan memberikan perhatian khusus pada pasien skizofrenia (Pardede, Sirait, Emanuel, \& Laia 2016). Ganguan jiwa di Indonesia pada tahun 2019 di urutan pertama Provinsi Bali 11,1\% dan nomor dua disusul oleh Provinsi DI Yogyakarta 10,4\%, NTB 9,6\%, Provinsi Sumatera Barat 9,1\%, Provinsi Sulawesi Selatan 8,8\%, Provinsi Aceh 8,7\%, Provinsi Jawa Tengah 8,7\%, Provinsi Sulawesi Tengah 8,2\%, Provinsi Sumatera Selatan 8\%, Provinsi Kalimantan Barat 7,9\%. Sedangkan Provinsi 
Sumatera Utara berada pada posisi ke 21 dengan prevalensi 6,3\% (Kemenkes, 2019).

Menurut Pardede \& Siregar, \& Halawa (2020) skizofrenia menimbulkan distorsi pikiran sehingga pikiran itu menjadi sangat aneh, juga distorsi persepsi seperti halusinasi, emosi, dan tingkah laku yang dapat mengarah ke perilaku kekerasan yang dapat berbahaya dengan diri sendiri maupun orang lain sekitar. Halusinasi merupakan distorsi persepsi palsu yang terjadi pada respon neurobiologist maladaptive, penderita sebenarnya mengalami distorsi sensori sebagai hal yang nyata dan meresponnya. Diperkirakan $\geq 90 \%$ penderita gangguan jiwa jenis halusinasi. dengan bentuk yang bervariasi tetapi sebagian besarnya mengalami halusinasi pendengaran yang dapat berasal dari dalam diri individu atau dari luar individu tersebut, suara yang didengar bisa dikenalnya, jenis suara tunggal atau multiple yang dianggapnya dapat memerintahkan tentang perilaku individu itu sendiri (Yosep \& Sutini, 2016).

Halusinasi pendengaran merupakan gangguan persepsi sensori yang paling sering dialami pasien dengan skizofrenia. Pasien dengan halusinasi pendengaran sering terlihat bercakap-cakap sendiri, dan bahkan melakukan sesuatu yang membahayakan (Barus \& Siregar, 2020). Halusinasi pendengaran adalah mendengar suara atau kebisingan yang kurang jelas ataupun yang jelas, dimana terkadang suara-suara tersebut seperti mengajak bicara klien dan kadang memerintah klien untuk melakukan sesuatu. Apabila gangguan halusinasi pendengaran tidak bisa dikontrol, maka dapat mengakibatkan atau dampaknya menciderai diri sendiri, orang lain dan lingkungan (Oktiviani, 2020).

Berdasarkan praktik keperawatan jiwa yang dilakukan di Ruang Dolok Sanggul II terdapat jumlah pasien 14 orang dan yang menjadi subjek dalam pemberian asuhan keperawatan jiwa ini adalah Tn. I yang mengalami gangguan persepsi sensori: Halusinasi Pendengaran. Penyebab Tn. I dijadikan sebagai subjek dikarenakan pasien masih sering mendengar suara-suara bisikan, tertawa sendiri, bicara sendiri dan sering mondar-mandir. 


\subsection{Tujuan Penulisan}

\subsubsection{Tujuan Umum}

Mahasiswa mampu memberikan asuhan keperawatan jiwa pada Tn. I dengan gangguan persepsi sensori : Halusinasi Pendengan di Rumah Sakit Jiwa Prof. Dr. Muhammad Ildrem di ruangan Dolok Sanggul II

\subsubsection{Tujuan Khusus}

1. Mahasiswa mampu mengetahui defenisi, tanda dan gejala, faktor penyebab, mekanisme koping penatalaksanaan pada Tn. I dengan halusinasi

2. Mahasiswa mampu melakukan pengkajian pada pasien dengan halusinasi

3. Mahasiswa mampu menegakkan diagnosa atau masalah keperawatan pada Tn. I dengan halusinasi

4. Mahasiswa mampu menetapkan intervensi keperawatan pada Tn.I dengan Halusinasi.

5. Mahasiswa mampu melakukan tindakan keperawatan pada Tn. I dengan Halusinasi

6. Mahasiswa mampu megevaluasi sebagai tolak ukur guna menerapkan asuhan keperawatan pada Tn. I dengan Halusinasi.

7. Mahasiswa mampu melakukan pendokumentasian pada Tn.I dengan halusinasi. 


\section{BAB 2 \\ TINJAUAN TEORITIS}

\subsection{Konsep Halusinasi}

\subsubsection{Defenisi}

Halusinasi merupakan distorsi persepsi palsu yang terjadi pada respon neurobiologist maladaptive, penderita sebenarnya mengalami distorsi sensori sebagai hal yang nyata dan meresponnya. Diperkirakan $\geq 90 \%$ penderita gangguan jiwa jenis halusinasi (Yosep \& Sutini, 2016). Halusinasi pendengaran paling sering terjadi ketika klien mendengar suara -suara, halusinasi ini sudah melebur dan pasien merasa sangat ketakutan, panik dan tidak bisa membedakan antara khayalan dan kenyataan yang dialaminya (Pardede, et al. 2021).

Halusinasi merupakan salah satu gejala gangguan jiwa dimana pasien mengalami perubahan sensorik dalam persepsi indra, ketidakmampuan untuk membedakan rangsangan internal (pikiran) dan rangsangan eksternal (dunia luar), adanya persepsi yang salah tentang ligkungan tanpa benda (Emulyani, 2020). Berdasarkan beberapa defenisi diatas dapat disimpulkan halusinasi merupakan gangguan persepsi panca indera, klien halusinasi ini biasanya mendengar suara-suara bisikan yang tidak nyata, klien merasa sangat ketakutan, panik dan tidak bisa membedakan antara khayalan dan kenyataan

\subsubsection{Etiologi}

Faktor predisposisi klien halusinasi menurut (Oktiviani, 2020) :

1. Faktor Predisposisi

a. Faktor perkembangan

Tugas perkembangan klien terganggu misalnya rendahnya kontrol dan kehangatan keluarga menyebabkan klien tidak mampu mandiri sejak kecil, mudah frustasi, hilang percaya diri. 


\section{b. Faktor sosiokultural}

Berbagai faktor di masyarakat dapat menyebabkan seseorang merasa disingkirkan oleh kesepian terhadap lingkungan tempat klien dibesarkan (Muhith, 2015).

c. Biologis

Faktor biologis Mempunyai pengaruh terhadap terjadinya gangguan jiwa. Adanya stress yang berlebihan dialami seseorang maka didalam tubuh akan dihasilkan suatu zat yang dapat bersifat halusinogen neurokimia. Akibat stress berkepanjangan menyebabkan teraktivasinya neurotransmitter otak.

d. Psikologis

Tipe kepribadian lemah dan tidak bertanggung jawab mudah terjerumus pada penyalahgunaan zat adikitif. Hal ini berpengaruh pada ketidakmampuan klien dalam mengambil keputusan yang tepat demi masa depannya, klien lebih memilih kesenangan sesaat dan lari dari alam nyata menuju alam khayal.

e. Sosial Budaya

Meliputi status sosial, umur, pendidikan, agama dan kondisi politik. Status social ekonomi, pendidikan yang rendah, kurangnya pengetahuan, motivasi yang kurang dan kondisi fisik yang lemah dapat mempengaruhi klien dalam mempertahankan aktifitas klien yang mengalami halusinasi.

\section{Faktor Presipitasi}

Faktor presipitasi merupakan stimulus yang dipersepsikan oleh individu sebagai tantangan, ancaman, atau tuntutan yang memerlukan energi ekstra untuk menghadapinya. Seperti adanya rangsangan dari lingkungan, misalnya partisipasi klien dalam kelompok, terlalu lama tidak diajak komunikasi, objek yang ada di lingkungan dan juga suasana sepi atau terisolasi, sering menjadi pencetus terjadinya halusinasi. Hal tersebut dapat meningkatkan stress dan kecemasan yang merangsang tubuh mengeluarkan zat halusinogenik. Penyebab Halusinasi dapat dilihat dari lima dimensi (Oktiviani, 2020) yaitu : 
a. Dimensi fisik: Halusinasi dapat ditimbulkan oleh beberapa kondisi fisik seperti kelelahan yang luar biasa, penggunaaan obat-obatan, demam hingga delirium, intoksikasi alkohol dan kesulitan untuk tidur dalam waktu yang lama.

b. Dimensi Emosional: Perasaan cemas yang berlebihan atas dasar problem yang tidak dapat diatasi merupakan penyebab halusinasi itu terjadi. Isi dari halusinasi dapat berupa perintah memaksa dan menakutkan. Klien tidak sanggup lagi menentang perintah tersebut hingga dengan kondisi tersebut klien berbuat sesuatu terhadap ketakutan tersebut.

c. Dimensi Intelektual: Dalam dimensi intelektual ini menerangkan bahwa individu dengan halusinasi akan memperlihatkan adanya penurunan fungsi ego. Pada awalnya halusinasi merupakan usaha dari ego sendiri untuk melawan impuls yang menekan, namun merupakan suatu hal yang menimbulkan kewaspadaan yang dapat mengambil seluruh perhatian klien dan tidak jarang akan mengontrol semua perilaku klien.

d. Dimensi Sosial: Klien mengalami interaksi sosial dalam fase awal dan comforting, klien meganggap bahwa hidup bersosialisasi di alam nyata sangat membahayakan. Klien asyik dengan Halusinasinya, seolah-olah ia merupakan tempat untuk memenuhi kebutuhan akan interaksi sosial, kontrol diri dan harga diri yang tidak didapatkan dakam dunia nyata.

e. Dimensi Spiritual: Secara sepiritual klien Halusinasi mulai dengan kehampaan hidup, rutinitas tidak bermakna, hilangnya aktifitas ibadah dan jarang berupaya secara sepiritual untuk menyucikan diri. Saat bangun tidur klien merasa hampa dan tidak jelas tujuan hidupnya. Individu sering memaki takdir tetapi lemah dalam upaya menjemput rezeki, menyalahkan lingkungan dan orang lain yang menyebabkan takdirnya memburuk. 


\subsubsection{Tanda Dan Gejala}

Menurut Yuanita (2019). Tanda dan gejala Halusinasi terdiri dari :

a. Menarik diri dari orang lain, dan berusaha untuk menghindar diri dari orang lain

b. Tersenyum sendiri, tertawa sendiri

c. Duduk terpukau (berkhayal)

d. Bicara sendiri

e. Memandang satu arah, menggerakan bibir tanpa suara, penggerakan mata yang cepat, dan respon verbal yang lambat

f. Menyerang, sulit berhubungan dengan orang lain

g. Tiba-tiba marah,curiga, bermusuhan, merusak (diri sendiri, orang lain dan lingkungan) takut

h. Gelisah, ekspresi muka tegang, mudah tersinggung, jengkel,

i. Terjadi peningkatan denyut jantung, pernapasan dan tekanan darah

\subsubsection{Rentang Respon Halusinasi}

Halusinasi merupakan salah satu respon maldaptive individual yang berbeda rentang respon neurobiologi dalam Ini merupakan persepsi maladaptive. Jika klien yang sehat persepsinya akurat, mampu mengidentifisikan dan menginterpretasikan stimulus berdasarkan informasi yang diterima melalui panca indera (pendengaran, pengelihatan, penciuman, pengecapan dan perabaan) klien halusinasi mempersepsikan suatu stimulus panca indera walaupun stimulus tersebut tidak ada. Diantara kedua respon tersebut adalah respon individu yang karena suatu hal mengalami kelainan persensif yaitu salah mempersepsikan stimulus yang diterimanya, yang tersebut sebagai ilusi. Klien mengalami jika interpresentasi yang dilakukan terhadap stimulus panca indera tidak sesuai stimulus yang diterimanya,rentang respon tersebut sebagai berikut (Pardede et al, 2021)

1. Respon Adaptif 
Respon adaptif adalah respon yang dapat diterima oleh norma-norma sosial budaya yang berlaku. Dengan kata lain individu tersebut dalam batas normal jika menghadapi suatu masalah akan dapat memecahkan masalah tersebut, respon adaftif :

a. Pikiran logis adalah pandangan yang mengarah pada kenyataan. Persepsi akurat adalah pandangan yang tepat pada kenyataan.

b. Emosi konsisten dengan pengalaman yaitu perasaan yang timbul dari pengalaman

c. Perilaku sosial adalah sikap dan tingkah laku yang masih dalam batas kewajaran.

d. Hubungan sosial adalah proses suatu interaksi dengan orang lain dan lingkungan.

2. Respon Maladaptif Respon maladaptif adalah respon individu dalam menyelesaikan masalah yang menyimpang dari norma-norma sosial budaya dan lingkungan, adapun respon maladaptif meliputi:

a. Kelainan pikiran adalah keyakianan yang secara kokoh dipertahankan walaupun tidak diyakini oleh orang lain dan bertetangan dengan kenyataan sosial

b. Halusinasi merupakan persepsi sensori yang salah atau persepsi eksternal yang tidak realita atau tidak ada.

c. Kerusakan proses emosi adalah perubahan sesuatu yang timbul dari hati.

d. Perilaku tidak terorganisir merupakan suatu yang tidak teratur.

e. Isolasi sosial adalah kondisi kesendirian yang dialami oleh individu dan diterima sebagai ketentuan oleh orang lain dan sebagai suatu kecelakaan yang negatif mengancam.

\subsubsection{Jenis - Jenis Halusinasi}

Menurut (Pardede et al, 2021), jenis halusinasi antara lain :

1. Halusinasi pendengaran (auditorik) $70 \%$ Karakteristik ditandai dengan mendengar suara, teruatama suara-suara orang, biasanya klien 
mendengar suara orang yang sedang membicarakan apa yang sedang dipikirkannya dan memerintahkan untuk melakukan sesuatu.

2. Halusinasi penglihatan (visual) $20 \%$ Karakteristik dengan adanya stimulus penglihatan dalam bentuk pancaran cahaya, gambaran geometrik, gambar kartun dan / atau panorama yang luas dan kompleks. Penglihatan bisa menyenangkan atau menakutkan.

3. Halusinasi penghidu (olfactory) Karakteristik ditandai dengan adanya bau busuk, amis dan bau yang menjijikkan seperti: darah, urine atau feses.Kadang - kadang terhidu bau harum.Biasanya berhubungan dengan stroke, tumor, kejang dan dementia.

4. Halusinasi peraba(tactile) Karakteristik ditandai dengan adanya rasa sakit atau tidak enak tanpa stimulus yang terlihat. Contoh : merasakan sensasi listrik datang dari tanah, benda mati atau orang lain.

5. Halusinasi pengecap (gustatory) Karakteristik ditandai dengan merasakan sesuatu yang busuk, amis dan menjijikkan, merasa mengecap rasa seperti rasa darah, urin atau feses.

6. Halusinasi cenesthetik

Karakteristik ditandai dengan merasakan fungsi tubuh seperti darah mengalir melalui vena atau arteri, makanan dicerna atau pembentukan urine.

7. Halusinasi kinesthetic Merasakan pergerakan sementara berdiri tanpa bergerak

\subsubsection{Fase-fase Halusinasi}

Halusinasi terbagi atas beberapa fase (Oktiviani, 2020):

a. Fase Pertama / Sleep disorder Pada fase ini Klien merasa banyak masalah, ingin menghindar dari lingkungan, takut diketahui orang lain bahwa dirinya banyak masalah. Masalah makin terasa sulit karna berbagai stressor terakumulasi, misalnya kekasih hamil, terlibat narkoba, dikhianati kekasih, masalah dikampus, drop out, dst. Masalah terasa menekan karena terakumulasi sedangkan support sistem kurang dan persepsi terhadap masalah sangat buruk. Sulit tidur berlangsung trus- 
menerus sehingga terbiasa menghayal. Klien menganggap lamunanlamunan awal tersebut sebagai pemecah masalah

b. Fase Kedua / Comforting Klien mengalami emosi yang berlanjut seperti adanya perasaan cemas, kesepian, perasaan berdosa, ketakutan, dan mencoba memusatkan pemikiran pada timbulnya kecemasan. Ia beranggapan bahwa pengalaman pikiran dan sensorinya dapat dia kontrol bila kecemasannya diatur, dalam tahap ini ada kecenderungan klien merasa nyaman dengan halusinasinya

c. Fase Ketiga / Condemning Pengalaman sensori klien menjadi sering datang dan mengalami bias. Klien mulai merasa tidak mampu lagi mengontrolnya dan mulai berupaya menjaga jarak antara dirinya dengan objek yang dipersepsikan klien mulai menarik diri dari orang lain, dengan intensitas waktu yang lama.

d. Fase Keempat / Penyakit Mental. Klien biasanya tidak dapat mengontrol diri mereka sendiri, kecemasan mereka parah dan halusinasi sangat menarik klien : pasien menyerah dan menerima pengalaman sensorik, isi ilusi menjadi menarik dan ketika pengalaman selesai pasien kesepian (Azizah, Zainuri \& Akbar, 2016).

e. Tahap Kelima (non-psikotik). Pada tahap ini, halusinasi dapat membuat klien merasa nyaman dan orientasi sedang. Secara umum pada tahap ini merupakan hal yang menyenangkan bagi klien : Mengalami kecemasan, kesepian, batin dan ketakutan,Cobalah untuk social pada pikiran yang dapat menghilangkan kecemasan dan Pikiran dan pengalaman indrawi masih di bawah kendali sadar (Azizah, Zainuri \& Akbar, 2016).

\subsubsection{Penatalaksanaan Halusinasi}

Penatalaksanaan pasien dengan halusinasi ada beberapa seperti farmakoterapi, terapi kejang listrik, psikoterapi dan rehabilitas yang diantaranya terapi okupasi, terapi sosial, TAK, terapi lingkungan (Prabowo, 2014). Terapi okupasi aktivitas menggambar terhadap perubahan halusinasi pada pasien skizofrenia hasil penelitian menunjukan $p=0,000$. Hasil tersebut 
menemukan adanya pengaruh terapi okupasi aktivitas menggambar terhadap perubahan halusinasi pada pasien skizofrenia Penelitian.

Aktivitas menanam yang dilakukan bertujuan untuk meminimalisasi interaksi pasien dengan dunianya yang tidak nyata, mengeluarkan pikiran, perasaan, ata emosi yang selama ini mempengaruhi perilaku yang tidak disadarinya, memberi motivasi dan memberikan kegembiraan, hiburan, serta mengalihkan perhatian pasien dari halusinasi yang dialami sehingga pikiran pasien tidak terfokus dengan halusinasinya khusus nya pada pasien halusinasi pendengaran (Fitri, 2019).

\subsection{Konsep Asuhan Keperawatan Jiwa}

\subsubsection{Pengkajian}

Pengkajian merupakan pengumpulan data subjektif dan objektif secara, sistematis dengan tujuan membuat penentuantindakan keperawatan bagi individu,kekuarga dan komunitas (Damayanti \& Iskandar,2014). Pada tahap ini ada beberapa yang perlu dieksplorasi baik pada klien yang berkenaan dengan kasus halusinasi yang meliputi :

a. Identitas klien Meliputi nama klien, umur, jenis kelamin, status perkawinan, Agama, tanggal MRS, informan, tanggal pengkajian, nomor rumah klien, dan alamat klien.

b. Keluhan utama. Keluhan utama Biasanya berupa bicara sendiri, tertawa sendiri, senyum sendiri, menggerakkan bibir tanpa suara, menarik diri dari orang lain, tidak dapat membedakan yang nyata dan tidak nyata, ekspresi muka tegang mudah tersinggung, jengkel dan marah ketakutan biasa terdapat disorientasi waktu tempat dan orang, tidak dapat mengurus diri dan tidak melakukan kegiatan sehari-hari.

c. Faktor predisposisi. Faktor predisposisi adalah faktor resiko yang mempengaruhi jenis dan jumlah sumber yang dapat dibangkitkan oleh individu untuk mengatasi stres. Diperoleh baik dari klien maupun keluarganya, mengenai faktor perkembangan sosial kultural, biokimia 
psikologis dan genetik yaitu faktor resiko yang mempengaruhi jenis dan jumlah sumber yang dapat dibangkitkan oleh individu untuk mengatasi stres.

a) Faktor perkembangan ; biasanya tugas perkembangan mengalami hambatan dan hubungan interpersonal terganggu maka individu akan mengalami stres dan kecemasan.

b) Faktor sosiokultural ; berbagai faktor di masyarakat dapat menyebabkan seseorang merasa disingkirkan oleh kesepian terhadap lingkungan tempat klien dibesarkan.

c) Faktor biokimia ; adanya stres yang berlebihan dialami seseorang maka di dalam tubuh akan dihasilkan suatu zat yang dapat bersifat halusinogenik neuro kimia.

d) Faktor psikologis; hubungan interpersonal yang tidak harmonis, adanya peran ganda yang bertentangan dan tidak diterima oleh anak akan mengakibatkan stres dan kecemasan yang tinggi dan berakhir dengan gangguan orientasi realitas seperti halusinasi.

e) Faktor genetik; Apa yang berpengaruh dalam skizoprenia. Belum diketahui, tetapi Hasil studi menunjukkan bahwa faktor keluarga menunjukkan hubungan yang sangat berpengaruh pada penyakit ini.

d. Faktor presipitasi Adanya rangsangan lingkungan yang sering yaitu seperti partisipasi klien dalam kelompok, terlalu lama Diajak komunikasi objek yang ada di lingkungan juga suasana sepi / isolasi adalah sering sebagai pencetus terjadinya halusinasi karena hal tersebut dapat meningkatkan stres dan kecemasan yang merangsang tubuh mengeluarkan zat halusinogenik.

e. Aspek fisik Hasil pengukuran tanda vital (TD, nadi, suhu, pernapasan, $\mathrm{TB}, \mathrm{BB}$ ) dan keluhan fisik yang dialami oleh klien. Terjadi peningkatan denyut jantung pernapasan dan tekanan darah.

f. Aspek psikososial Genogram yang menggambarkan tiga generasi.

g. Konsep diri 
1. Citra tubuh Menolak melihat dan menyentuh bagian tubuh yang berubah/ tidak menerima perubahan tubuh yang terjadi / yang akan terjadi. Menolak penjelasan perubahan tubuh, persepsi negatif tentang tubuh. Preokupasi dengan bagian tubuh yang hilang, mengungkapkan keputusasaan, mengungkapkan ketakutan.

2. Identitas diri Ketidakpastian memandang diri, sukar menetapkan keinginan dan tidak mampu mengambil keputusan.

3. Peran Berubah / berhenti fungsi peran yang disebabkan penyakit, proses menua putus sekolah dan PHK.

4. Identitas diri Mengungkapkan keputusasaan karena penyakitnya dan mengungkapkan keinginan yang terlalu tinggi

5. Harga diri Perasaan malu terhadap diri sendiri, rasa bersalah terhadap diri sendiri, gangguan hubungan sosial, merendahkan martabat, mencederai diri dan kurang percaya diri.

h. Status mental

Pada pengkajian status mental pasien halusinasi ditemukan data berupa bicara sendiri, senyum sendiri, tertawa sendiri, menggerakkan bibir tanpa suara, pergerakan mata yang cepat, respon verbal yang lambat, menarik diri dari orang lain berusaha untuk menghindari orang lain, tidak dapat membedakan yang nyata dan tidak nyata, terjadi peningkatan denyut jantung pernapasan dan tekanan darah, perhatian dengan lingkungan yang kurang / hanya beberapa detik com berkonsentrasi dengan pengalaman sensori, sulit berhubungan dengan orang lain, ekspresi muka tegang, mudah tersinggung, jengkel dan marah tidak mampu mengikuti perintah dari perawat, tampak tremor dan berkeringat, perilaku panik, agitasi dan kataton curiga dan bermusuhan, bertindak merusak diri orang lain dan lingkungan, ketakutan, tidak dapat mengurus diri, biasa terdapat disorientasi waktu tempat dan orang.

i. Mekanisme koping Apabila mendapat masalah, pasien takut / tidak mau menceritakan kepada orang lain (koping menarik diri). Mekanisme koping yang digunakan pasien sebagai usaha mengatasi kecemasan yang 
merupakan suatu kesepian nyata yang mengancam dirinya. Mekanisme koping yang sering digunakan pada halusinasi adalah :

1. Regresi : menjadi malas beraktivitas sehari-hari.

2. Proyeksi : menjelaskan perubahan suatu persepsi dengan berusaha untuk mengalihkan tanggung jawab kepada orang lain.

3. Menarik diri : sulit mempercayai orang lain dan asyik dengan stimulus internal.

j. Aspek medik Terapi yang diterima klien bisa berupa terapi farmakologi psikomotor terapi okupasional, TAK dan rehabilitas.

\subsubsection{Diagnosa Keperawatan}

Menurut NANDA 2015 - 2017 yakni gangguan persepsi. Dengan faktor berhubungan dan batasan karakteristik disesuaikan dengan keadaan yang ditemukan pada tiap -tiap partisipan. Topik yang diteliti yakni kemampuan mengontrol halusinasi pendengaran.

\subsubsection{Perencanaan Keperawatan}

Rencana tindakan pada keluarga (Husein,\& Arifin,2011)adalah;

a. Diskusikan masalah yang dihadap keluarga dalam merawat pasien

b. Berikan penjelasan meliputi : pengertian halusinasi, proses terjadinya halusinasi, jenis halusinasi yang dialami, tanda dan gejala halusinasi, proses terjadinya halusinasi.

c. Jelaskan dan latih cara merawat anggota keluarga yang mengalami halusinasi : menghardik, minum obat, bercakap-cakap, melakukan aktivitas.

d. Diskusikan cara menciptakan lingkungan yang dapat mencegah terjadinya halusinasi.

e. Diskusikan tanda dan gejala kekambuhan

f. Diskusikan pemanfaatan fasilitas pelayanan kesehatan terdekat untuk follow up anggota keluarga dengan halusinasi. 
Rencana tindakan keperawatan pada klien dengan diagnosa gangguan persepsi sensori halusinasi meliputi pemberian tindakan keperawatan berupa terapi (Sulah, Pratiwi,\& Teguh. 2016) yaitu :

1. Bantu klien mengenal halusinasinya meliputi isi, waktu terjadi halusinasi, isi, frekuensi, perasaan saat terjadi halusinasi respon klien terhadap halusinasi mengontrol halusinasi dengan cara menghardik.

2. Meminum obat secara teratur.

3. Melatih bercakap-cakap dengan orang lain.

4. Menyusunkegiatanterjadwal dan dengan aktifitas

\subsubsection{Implementasi Keperawatan}

Implementasi disesuaikan dengan rencana tindakan keperawatan. Adapun pelaksanaan tindakan keperawatan jiwa dilakukan berdasarkan Strategi Pelaksanaan (SP) yang sesuai dengan masing-masing masalah utama. Pada saat akan dilaksanakan tindakan keperawatan maka kontrak dengan klien dilaksanakan dengan menjelaskan apa yang akan dikerjakan dan peran serta klien yang diharapkan, dokumentasikan semua tindakan yang telah dilaksanakan serta respon klien (Hafizudiin,2021).

\subsection{Evaluasi Keperawatan}

Evaluasi adalah proses hasil atau sumatif dilakukan dengan membandingkan respon klien pada tujuan umum dan tujuan khusus yang telah ditentukan.halusinasi pendengaran tidak terjadi perilaku kekerasan, klien dapat membina hubungan saling percaya, klien dapat mengenal halusinasinya, klien dapat mengontrol halusinasi dengar dari jangka waktu 4x24 jam didapatkan data subjektif keluarga menyatakan senang karena sudah diajarkan teknik mengontrol halusinasi, keluarga menyatakan pasien mampu melakukan beberapa teknik mengontrol halusinasi. Data objektif pasien tampak berbicara sendiri saat halusinasi itu datang, pasien dapat berbincang - bincang dengan orang lain, pasien mampu melakukan aktivitas terjadwal, dan minum obat secara teratur (Hafizudiin,2021). 


\section{BAB 3}

\section{ASUHAN KEPERAWATAN}

\subsection{Identitas Klien}

Inisial

Alamat

Tanggal Pengkajian

Umur

Agama

Status

Infoment
: Tn. I

: JL. Jalak No.39 Kelurahan Kenanga

: 09 Februari 2022

: 51 Tahun

: Islam

: Single

: Status pasien dan komunikasi dengan pasien

\subsection{Alasan Masuk Rumah Sakit}

klien masuk RSJ. Prof. Dr. Muhammad Ildrem jiwa adalah Klien Awalnya marahmarah, bicara sendiri, dan sulit tidur.

\subsection{Faktor Predisposisi}

Klien sebelumnya pernah mengalami gangguan jiwa dimasa lalu, klien pernah opname di RS Jiwa tetapi sampai rumah tidak minum obat, klien ingin menjadi orang hebat tetapi tidak berhasil.

\subsection{Fisik}

Saat dilakukan pemeriksaan tanda-tanda vital, didapatkan hasil TD : 120/80 mmHg ; N : 80x/i ; S : 36,6 oC ; RR : 20x/i. Klien memiliki tinggi badan $132 \mathrm{~cm}$ dan berat badan $80 \mathrm{Kg}$.

\subsection{Psikososial}

\subsubsection{Genogram}




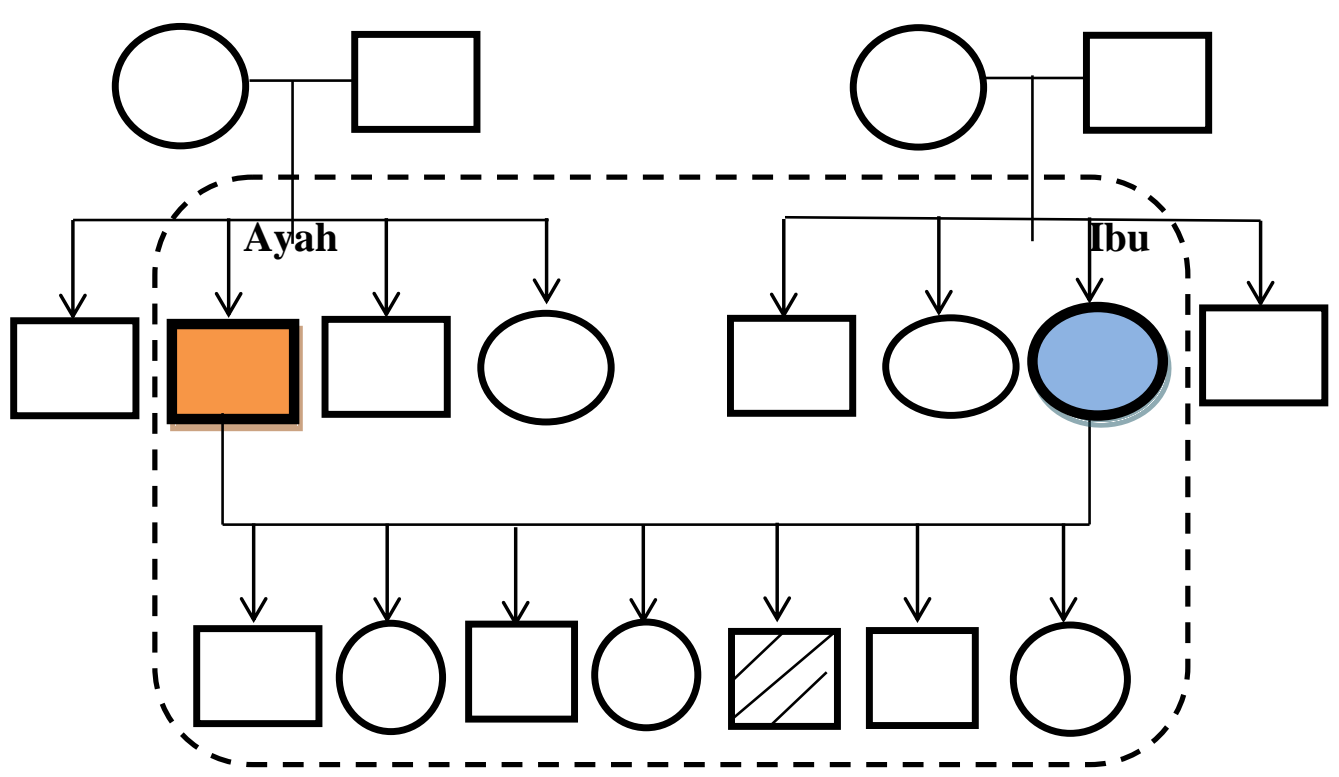

Keterangan :

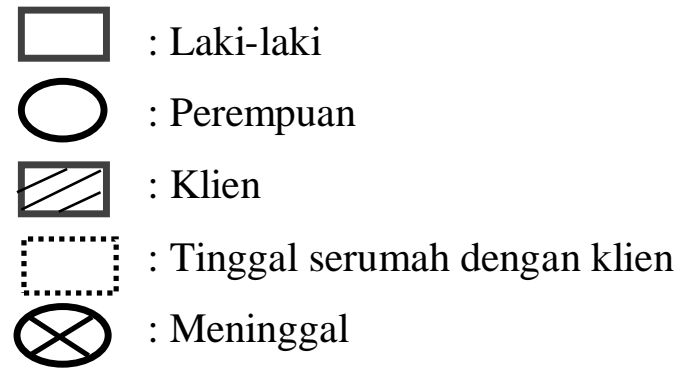

klien anak ke-5 dari 7 bersaudara

\subsubsection{Konsep diri}
a. Gambaran diri
: pasien menyukai semua anggota tubuhnya
b. Identitas
: pasien mampu menyebutkan nama dan alamat
c. Peran
: pasien berperan sebagai anak
d. Ideal diri
: pasien ingin cepat sembuh
e. Harga diri
: pasien merasa dibuang oleh keluarga
Masalah keperawatan : Gangguan Konsep Diri : Harga Diri Rendah

\subsubsection{Hubungan social}

Pasien tidak berperan dalam kegiatan masyarakat, pasien tidak berhubungan dengan orang lain karena pasien malu dengan penyakitnya. 


\subsubsection{Spiritual}

a. Nilai dan keyakinan : Pasien beragaman islam

b. Kegiatan ibadah : Pasien rajin beribadah

3.5.5 Status Mental

a. Penampilan

: tidak rapi, rambut beratakan, baju kotor

b. Pembicaraan

: jelas

c. Aktivitas Motorik

: tidak ada masalah

d. Suasana perasaan

: sedih

e. Afek

: sesuai

f. Interaksi selama wawancara

: pasien kooperatif

g. Persepsi

: mendengar suara bisikan, bicara sendiri, mondar-mandir diruangan, dan tertawa sendiri

h. Proses Pikir

: sesuai

i. Isi pikir

: tidak ada waham

j. Tingkat kesadaran

: bingung

k. Memori

: mampu mengingat kejadian yang sudah lewat

1. Tingkat konsentrasi berhitung : pasien mampu berhitung sederhana

m. Kemampuan penilaian $\quad$ : pasien mampu menilai baik atau buruk

n. Daya titik diri : pasien kadang mengingkari penyakitnya

\subsection{Mekanisme Koping}

Klien mengalami mekanisme koping adaptif yaitu klien dapat berbicara baik dengan orang lain dan berkooperatif 


\subsection{Masalah Psikososial dan Lingkungan}

Klien mengatakan jarang mengikuti kegiatan dimasyarakat karena klien malu dengan penyakitnya.

\subsection{Pengetahuan Kurang Tentang Gangguan Jiwa}

Klien mengetahui tentang gangguan jiwa dan klien paham tentang penyakitnya dan apa saja obat yang harus diminum dan kapan saja.

\subsection{Analisis Data}

\begin{tabular}{|c|c|c|}
\hline No & Analisa Data & Masalah keperawatan \\
\hline 1. & $\begin{array}{l}\text { DS: } \\
\text { klien sering mendengar suara-suara bisikan } \\
\text { DO : } \\
\text { Klien tampak mendengar suara bisikan, bicara } \\
\text { sendiri, mondar-mandir diruangan, tertawa sendiri }\end{array}$ & $\begin{array}{llr}\text { Gangguan } & \text { Persepsi } \\
\text { Sensori } & : & \text { Halusinasi } \\
\text { Pendengaran } & & \end{array}$ \\
\hline 2. & $\begin{array}{l}\text { DS: } \\
\text { klien mengatakan malas berperan dalam kegiatan } \\
\text { masyarakat } \\
\text { DO : } \\
\text { Klien tampak suka menyendiri di dalam ruangan, } \\
\text { tampak menghindari interaksi, terlihat sedih, } \\
\text { pandangan menunduk kebawah }\end{array}$ & Isolasi Sosial: MenarikDiri \\
\hline 3. & $\begin{array}{l}\text { DS : } \\
\text { Klien merasa dibuang oleh keluarganya dan malu } \\
\text { dengan penyakitnya } \\
\text { DO : } \\
\text { Klien tampak murung dan tidak bisa } \\
\text { mempertahankan kontak mata dengan perawat, } \\
\text { klien tampak lebih banyak diam, nada bicara pelan }\end{array}$ & $\begin{array}{l}\text { Gangguan Konsep Diri } \\
\text { : Harga diri rendah kronis }\end{array}$ \\
\hline
\end{tabular}




\subsection{Daftar Masalah Keperawatan}

1. Gangguan Persepsi Sensori : Halusinasi Pendengaran

2. Isolasi Sosial : Menarik Diri

3. Gangguan Konsep Diri : Harga Diri Rendah Kronis

\subsection{Pohon Masalah}

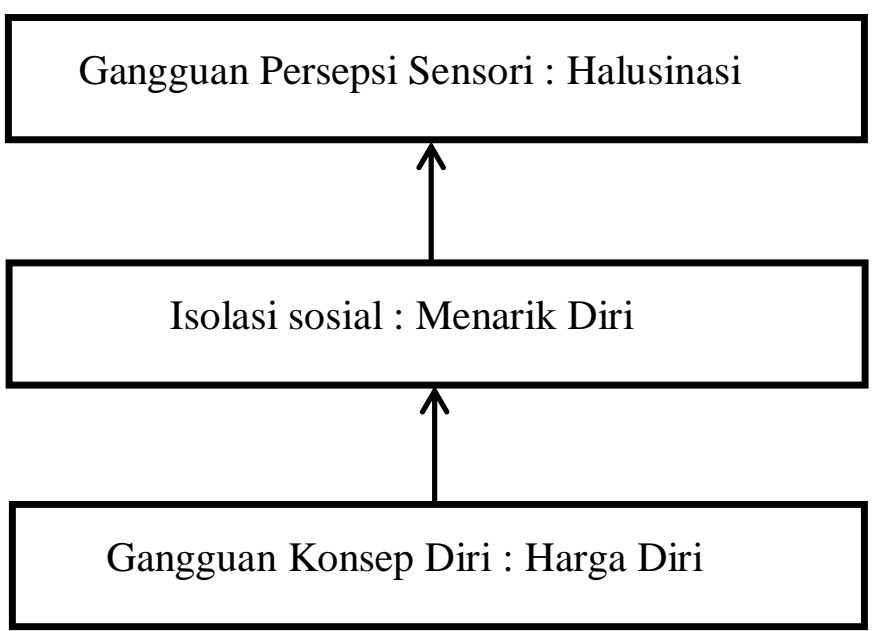

\subsection{Diagnosa Prioritas}

Gangguan Persepsi Sensori : Halusinasi Pendengaran

\subsection{Intervensi Keperawatan}

\begin{tabular}{|l|l|l|}
\hline No & Diagnosa Keperawatan & Intervensi \\
\hline
\end{tabular}




\begin{tabular}{|c|c|c|}
\hline 1. & $\begin{array}{l}\text { Gangguan Persepsi Sensori : } \\
\text { Halusinasi Pendengaran }\end{array}$ & $\begin{array}{l}\text { SP 1: } \\
\text { 1. Mengidentifikasi isi, frekuensi, } \\
\text { waktu terjadi, situasi pencetus, } \\
\text { perasaan daan respon halusinasi } \\
\text { 2. Mengontrol halusinasi dengan } \\
\quad \text { menghardik } \\
\text { SP 2: } \\
\text { Mengontrol halusinasi dengan } \\
\text { minum obat secara teratur } \\
\text { SP 3: } \\
\text { Mengontrol halusinasi dengan } \\
\text { bercakap-cakap dengan orang lain } \\
\text { SP 4: } \\
\text { Mengontrol halusinasi dengan } \\
\text { melakukan kegiatan terjadwal }\end{array}$ \\
\hline 2. & Isolasi Sosial : Menarik Diri & $\begin{array}{l}\text { SP 1 : } \\
\text { Menjelaskan keuntungan dan } \\
\text { kerugian mempunyai teman } \\
\text { SP 2 : } \\
\text { Melatih klien berkenalan dengan } 2 \\
\text { orang atau lebih } \\
\text { SP 3 : } \\
\text { Melatih klien bercakap-cakap } \\
\text { sambilmelakukan kegiatan harian } \\
\text { SP. 4 : } \\
\text { Melatih klien berbicara social : } \\
\text { meminta sesuatu, berbelanja, dan } \\
\text { sebagainya }\end{array}$ \\
\hline 3. & $\begin{array}{l}\text { Gangguan Konsep Diri : Harga } \\
\text { Diri }\end{array}$ & $\begin{array}{l}\text { SP 1 : } \\
\text { Mengidentifikasi kemampuan dan } \\
\text { aspek positif yang dimilki pasien } \\
\text { SP 2 : } \\
\text { 1. Memilih kemampuan yang dapat } \\
\quad \text { digunakan } \\
\text { 2. Menetapkan/memilih kegiatan } \\
\quad \text { sesuai kemampuan } \\
\text { 3. Melatih kegiatan } \\
\quad \text { kemampuan yang dipilih } 1 \\
\text { SP } 3 \text { : } \\
\text { Melatih kegiatan sesuai kemampuan } \\
\text { yang dipilih } 2 \\
\text { SP } 4 \text { : } \\
\text { Melatih kegiatan sesuai kemampuan } \\
\text { yang dipilih } 3\end{array}$ \\
\hline
\end{tabular}

\subsection{Implementasi Dan Evaluasi Keperawatan}




\begin{tabular}{|c|c|c|}
\hline Hari/Tgl & Implementasi & Evaluasi \\
\hline $\begin{array}{l}\text { Kamis, } 27 \\
\text { Januari } \\
2022 \\
11.00\end{array}$ & $\begin{array}{l}\text { 1. Data } \\
\text { Tanda dan gejala: } \\
\text { bicara sendiri, tampak } \\
\text { mendengar suara bisikan, } \\
\text { mondar-mandir diruangan, } \\
\text { tertawa sendiri. } \\
\text { Diagnosa Keperawatan } \\
\text { Husinasi pendengaran } \\
\text { 2. Tindakan Keperawatan } \\
\text { Sp1halusinasi } \\
\text { - Melatih } \\
\text { mengidentifikasi } \\
\text { halusinasinya; } \\
\text { frekuensi, watu terjadi, } \\
\text { situasi pencetus, perasaan } \\
\text { dan respon halusinasi } \\
\text { - Mengontrol halusinasi } \\
\text { dengan cara menghardik } \\
\text { 3. RTL } \\
\text { Sp2; mengontrol halusinasi } \\
\text { dengan cara minum obat } \\
\text { dengan cara bercakap-cakap }\end{array}$ & $\begin{array}{l}\text { S : klien mengatakan marah saat } \\
\text { suara bisikan mengejeknya } \\
\text { O: } \\
\text { - Pasien mampu mengenali } \\
\text { halusinasi yang dialami nya; } \\
\text { isi, frekuensi, watu terjadi, } \\
\text { situasi pencetus, perasaan, } \\
\text { respon dengan mandiri } \\
\text { - Pasien mampu mengontrol } \\
\text { halusinasinya dengan cara } \\
\text { menghardik dengan bantuan }\end{array}$ \\
\hline $\begin{array}{l}\text { Jumat, } 28 \\
\text { Januari } \\
2022 \\
11.00\end{array}$ & $\begin{array}{l}\text { 1. Data } \\
\text { Tanda dan gejala: } \\
\text { bicara sendiri, tampak } \\
\text { mendengar suara bisikan, } \\
\text { mondar-mandir diruangan, } \\
\text { tertawa sendiri. }\end{array}$ & $\begin{array}{l}\text { S: setelah mengikuti terapi } \\
\text { Klien me r a s a Senang dan } \\
\text { antusias mengikuti terapi } \\
\text { O: } \\
\text { - klien mampu mengontrol } \\
\text { halusinasi dengan minum }\end{array}$ \\
\hline
\end{tabular}




\begin{tabular}{|c|c|c|}
\hline & $\begin{array}{l}\text { Diagnosa Keperawatan: } \\
\text { Husinasi pendengaran } \\
\text { 2. Tindakan Keperawatan } \\
\text { Sp2: Memberikan informasi } \\
\text { tentang cara pengunaan obat } \\
\text { minum obat } \\
\text { Sp3: memberikan informasi } \\
\text { dampak positif mengontrol } \\
\text { halusinasi dengan cara } \\
\text { bercakap-cakap dengen } \\
\text { orang lain } \\
\text { RTL: } \\
\text { Sp4 : Mengontrol halusinasi } \\
\text { dengan cara melakukan } \\
\text { aktivitas }\end{array}$ & 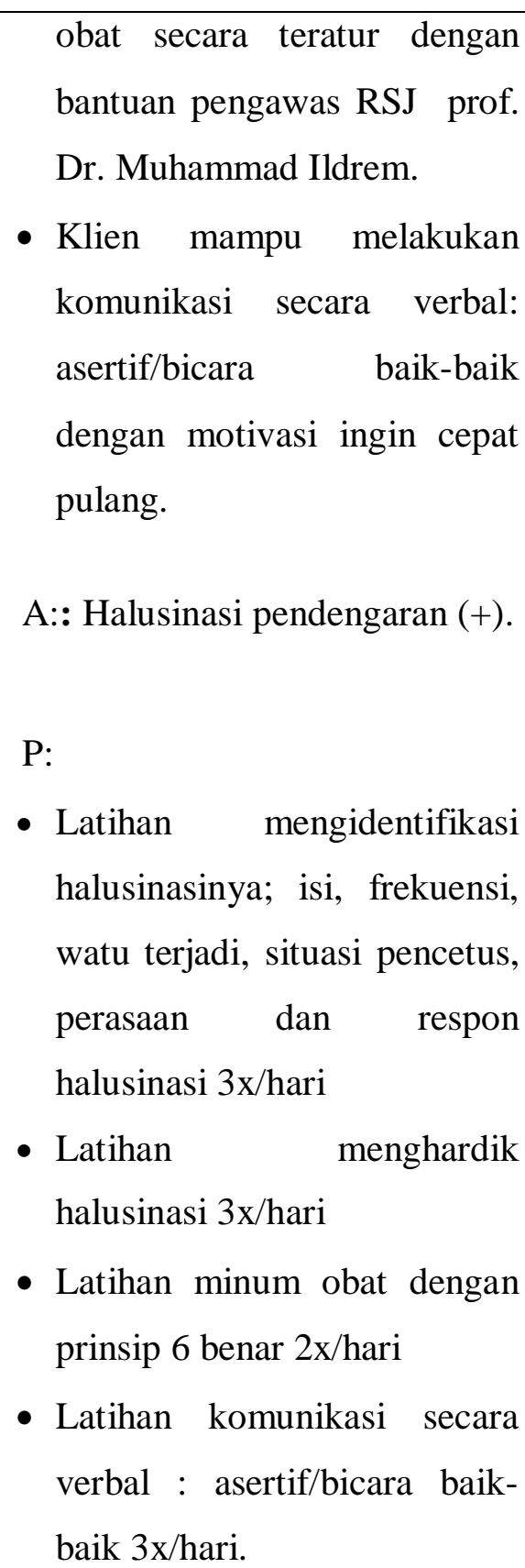 \\
\hline $\begin{array}{l}\text { Sabtu, } 29 \\
\text { Januari } \\
2022 \\
11.00\end{array}$ & $\begin{array}{l}\text { 1. Data } \\
\text { Tanda dan gejala: bicara } \\
\text { sendiri, tampak mendengar } \\
\text { suara bisikan, mondar- } \\
\text { mandir diruangan, tertawa } \\
\text { sendiri. } \\
\text { Diagnosa Keperawatan : } \\
\text { Halusinasi pendengaran }\end{array}$ & $\begin{array}{l}\text { S: klien mengatakan dia merasa } \\
\text { senang bisa bercakap-cakap } \\
\text { dengan orang lain } \\
\text { O:Klien mempraktekkan cara } \\
\text { bercakap-cakap dengan orang } \\
\text { lain } \\
\text { A:Halusinasi pendengaran }(+) \\
\text { P:Intervensi dilanjutkan }\end{array}$ \\
\hline
\end{tabular}




\begin{tabular}{|c|c|c|}
\hline & $\begin{array}{l}\text { 2. Tindakan keperawatan } \\
\text { Sp4: Halusinasi } \\
\text { - Mengevaluasi } \\
\text { kemampuan Menghardik } \\
\text { Halusinasi } \\
\text { - Melatih pasien untuk } \\
\text { melakukan kegiatan } \\
\text { spritual dengan cara } \\
\text { berdoa. } \\
\text { RTL: } \\
\text { Halusinasi : Follow up dan } \\
\text { evaluasi Sp1-4 Halusinasi }\end{array}$ & $\begin{array}{l}\text { - Latihan menghardik } \\
\text { halusinasi } 3 \mathrm{x} / \mathrm{hari} \\
\text { - Latihan minum obat dengan } \\
\text { prinsip } 6 \text { benar } 2 \mathrm{x} / \mathrm{hari} \\
\text { - Latihan bercakap-cakap } \\
\text { dengan orang lain } 3 \mathrm{x} / \text { hari } \\
\text { - Latihan kegiatan spritual }\end{array}$ \\
\hline $\begin{array}{l}\text { Rabu,02 } \\
\text { Februari } \\
2022 \\
15.00\end{array}$ & $\begin{array}{l}\text { 1. Data } \\
\text { Tanda dan gejala : klien } \\
\text { tampak suka menyendiri di } \\
\text { dalam ruangan, tampak } \\
\text { menghindari interaksi, } \\
\text { terlihat sedih, pandangan } \\
\text { menunduk kebawah } \\
\text { 2. Diagnosa keperawatan : } \\
\text { Isolasi sosial : Menarik diri } \\
\text { 3. Tindakan keperawatan: } \\
\text { SP } 1 \text { : } \\
\text { - Menjelaskan keuntungan } \\
\text { dan kerugian memiliki } \\
\text { teman } \\
\text { 4. RTL } \\
\text { - SP } 2 \text { Melatih klien } \\
\text { orang atau lebih }\end{array}$ & $\begin{array}{l}\mathrm{S}: \text { Klien hambatan dalam } \\
\text { berhubungan mengatakan } \\
\text { dengan orang lain karena klien } \\
\text { sulit bergaul dan selalu berdiam } \\
\text { diri } \\
\text { O : Paasien mampu memahami } \\
\text { keuntungan dan kerugian } \\
\text { memiliki teman } \\
\text { A: Isolasi Sosial : Menarik diri (+) } \\
\text { P: } \\
\text { - Menjelaskan keuntungan dan } \\
\text { kerugian memiliki teman } 3 x / h a r i \\
\text { - Melatih klien berkenalan } 2 \text { orang } \\
\text { atau lebih 3x/hari }\end{array}$ \\
\hline
\end{tabular}




\begin{tabular}{|c|c|c|}
\hline & $\begin{array}{l}\text { - SP } 3 \text { : melatih klien } \\
\text { bercakap-cakap sambil } \\
\text { melakukan aktifitas } \\
\text { terjadwal }\end{array}$ & \\
\hline $\begin{array}{l}\text { Kamis, } 03 \\
\text { Febuari } \\
2022\end{array}$ & $\begin{array}{l}\text { 1. Data } \\
\text { Tanda dan gejala : Klien } \\
\text { tampak suka menyendiri di } \\
\text { dalam ruangan, tampak } \\
\text { menghindari interaksi, } \\
\text { terlihat sedih, pandangan } \\
\text { menunduk kebawah } \\
\text { 2. Diagnosa keperawatan : } \\
\text { Isolasi sosial : Menarik diri } \\
\text { 3. Tindakan keperawaatan : } \\
\text { SP } 2 \text { : melatih klien } \\
\text { berkenalan dengan } 2 \text { orang } \\
\text { atau lebih } \\
\text { 4. RTL : } \\
\text { SP } 3 \text { : Melatih klien } \\
\text { bercakap-cakap sambil } \\
\text { melakukan aktivitas harian }\end{array}$ & $\begin{array}{l}\text { S : setelah mengikuti terapi klien } \\
\text { merasa Senang dan antusias } \\
\text { mengikuti terapi } \\
\text { O : Kien mampu berkenalan } \\
\text { dengan } 2 \text { orang atau lebih } \\
\text { A : Isolasi sosial : Menarik diri (+) } \\
\text { P : Intervensi lanjutan } \\
\text { - Melatih klien berkenalan } \\
\text { dengan } 2 \text { orang atau lebih } \\
\text { 3x/hari } \\
\text { - Melatih klien bercakap-cakpa } \\
\text { sambil melakukan aktivitas } \\
\text { harian } 3 x / h a r i\end{array}$ \\
\hline $\begin{array}{l}\text { Jumat, } 4 \\
\text { febuari } \\
2022 \\
15.00\end{array}$ & $\begin{array}{l}\text { 1. Data } \\
\text { Tanda dan gejala : } \\
\text { tampak menghindari } \\
\text { interaksi, terlihat sedih, } \\
\text { pendangan menunduk }\end{array}$ & $\begin{array}{l}\text { S : klien merasa senang bisa } \\
\text { bercakap-cakap sambil } \\
\text { melakukan kegiatan harian } \\
\text { O : klien mampu bercakap-cakap } \\
\text { sambil melakukan aktivitas }\end{array}$ \\
\hline
\end{tabular}




\begin{tabular}{|c|c|c|}
\hline & $\begin{array}{l}\text { kebawah } \\
\text { 2. Diagnosa keperawatan : } \\
\text { Isolasi sosial : Menarik diri } \\
\text { 3. Tindakan keperawaatan: } \\
\text { SP } 3: \text { Melatih klien } \\
\text { bercakap-cakap sambil } \\
\text { melakukan aktivitas harian } \\
\text { 4. Rtl : } \\
\text { SP 4: Melatih klien } \\
\text { berbicara sosial : meminta } \\
\text { sesuatu, belanja dan } \\
\text { sebagainya }\end{array}$ & $\begin{array}{l}\text { harian } \\
\text { A: Isolasi sosial : Menarik diri (+) } \\
\text { P : } \\
\text { - Melatih klien berkenalan } \\
\text { dengan } 2 \text { orang atau lebih } \\
\text { 3x/hari } \\
\text { - Melatih klien bercakap-cakap } \\
\text { sambil melakukan aktivitas } \\
\text { harian } 3 x / h a r i \\
\text { - Melatih klien berbicara sosial } \\
\text { : meminta sesuatu, belanja } \\
\text { dan sebagainya }\end{array}$ \\
\hline $\begin{array}{l}\text { Sabtu, } 5 \\
\text { febuari } \\
2022 \\
15.00\end{array}$ & $\begin{array}{l}\text { 1. Data } \\
\text { Tanda dan gejala : tampak } \\
\text { menghindari interaksi, } \\
\text { terlihat sedih, pendangan } \\
\text { menunduk kebawah } \\
\text { 2. Diagnosa keperawatan : } \\
\text { Isolasi sosial : Menarik diri } \\
\text { 3. Tindakan keperawaatan : } \\
\text { SP } 4 \text { : Melatih klien berbicara } \\
\text { sosial : meminta sesuatu, } \\
\text { belanja dan sebagainya } \\
\text { 4. RTL : } \\
\text { Isolasi sosial : Menarik diri: } \\
\text { Follow up dan evaluasi Sp1-4 } \\
\text { Isolasi sosial : Menarik diri }\end{array}$ & $\begin{array}{l}\text { S : Klien mengatakan senang } \\
\text { sudah mampu bercakap dan } \\
\text { berbicara sosial kepada teman } \\
\text { sekamar } \\
\text { O: klien mampu berbicara } \\
\text { sosial meminta tolong } \\
\text { A : Isolasi sosial : Menarik diri (+) } \\
\text { P : } \\
\text { - Latihan berkenalan dengan } 2 \\
\text { orang atau lebih } 3 x / h a r i \\
\text { - Latihan bercakap-cakap sambil } \\
\text { melakukan aktivitas harian } \\
\text { 3x/hari } \\
\text { - Melatih klien berbicara } \\
\text { sosial : meminta sesuatu, } \\
\text { belanja dan sebagainya. }\end{array}$ \\
\hline
\end{tabular}




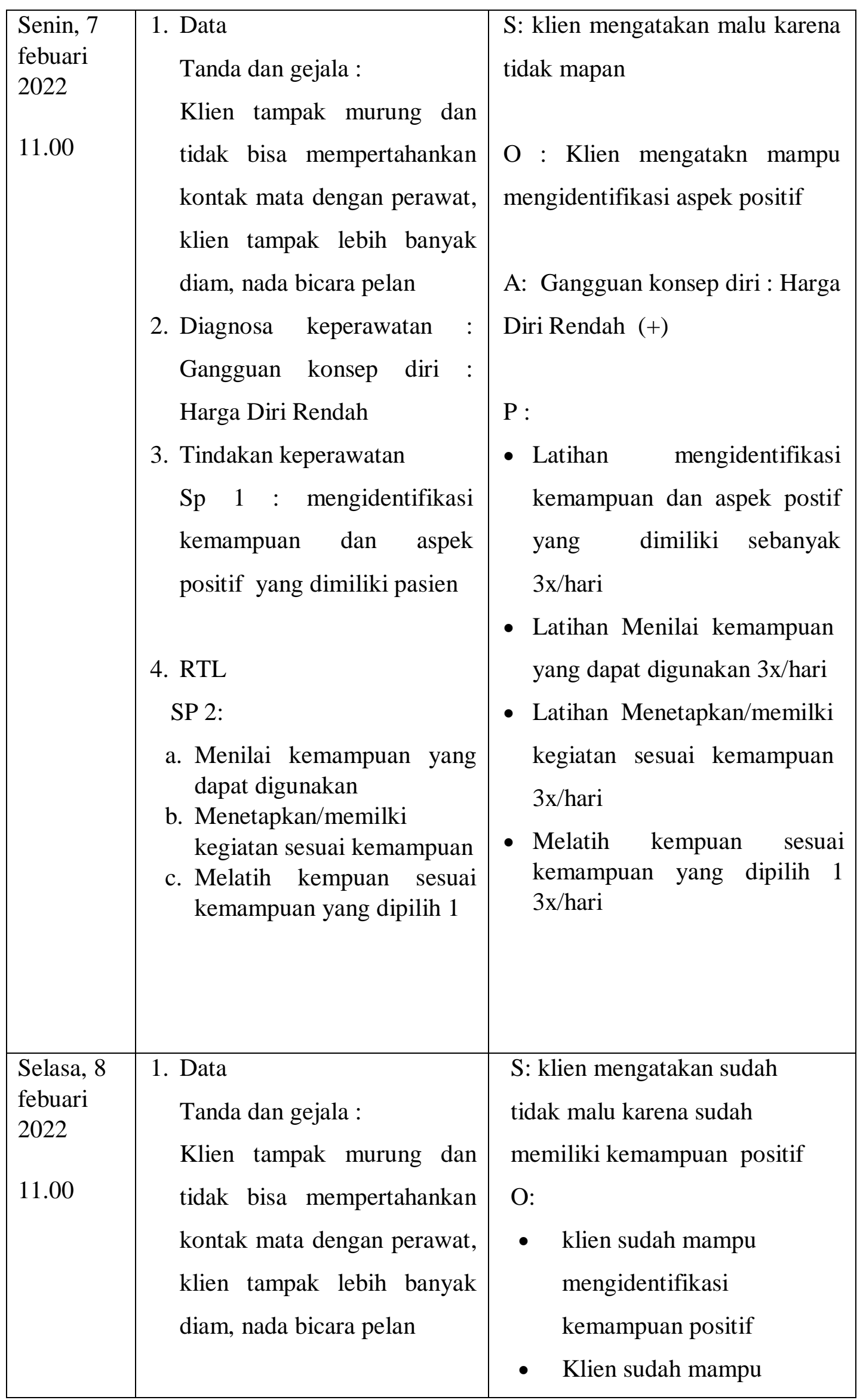




\begin{tabular}{|c|c|c|}
\hline & $\begin{array}{l}\text { 2. Diagnosa keperawatan: } \\
\text { Gangguan konsep diri : } \\
\text { Harga Diri Rendah } \\
\text { 3. Tindakan keperawatan } \\
\text { Sp } 2 \text { : } \\
\text { a. Menilai kemampuan yang } \\
\text { dapat digunakan } \\
\text { b. Menetapkan/memilki } \\
\text { kegiatan sesuai kemampuan } \\
\text { c. Melatih kempuan sesuai } \\
\text { kemampuan yang dipilih } 1 \\
\text { 4. RTL } \\
\text { SP 3: Melatih kemampuan } \\
\text { sesuai kemampuan yang } \\
\text { dipilih } 2\end{array}$ & $\begin{array}{l}\text { menilai kemapuan yang } \\
\text { digunakan } \\
\text { - } \quad \text { Klien sudah mampu } \\
\text { menetapkan keampuan } \\
\text { A: Gangguan konsep diri : } \\
\text { Harga Diri Renda (+) } \\
\text { P : } \\
\text { - } \quad \text { Latih kemampuan yang } \\
\text { dipili } 1 \text { (3x/hari) } \\
\text { Latih kemampuan yang } \\
\text { dipilih 2 (3x/hari) }\end{array}$ \\
\hline $\begin{array}{l}\text { Rabu, } 09 \\
\text { febuari } \\
2022 \\
11.00\end{array}$ & $\begin{array}{l}\text { 1. Data } \\
\text { Tanda dan gejala: } \\
\text { Klien tampak murung dan } \\
\text { tidak bisa mempertahankan } \\
\text { kontak mata dengan perawat, } \\
\text { klien tampak lebih banyak } \\
\text { diam, nada bicara pelan } \\
\text { 2. Diagnosa keperawatan : } \\
\text { Gangguan konsep diri : } \\
\text { Harga Diri Rendah } \\
\text { 3. Tindakan keperawatan } \\
\text { SP 3: Melatih kemampuan } \\
\text { sesuai kemampuan yang } \\
\text { dipilih } 2 \\
\text { 4. Rtl } \\
\text { SP } 4 \text { : Melatih kemampuan } \\
\text { sesuai kemampuan yang }\end{array}$ & $\begin{array}{l}\text { S: klien mengatakan sudah } \\
\text { mampu melatih kegiatan } \\
\text { bermain gitar } \\
\text { O: } \\
\text { - Klien sudah mampu } \\
\quad \text { melatih kegiatan bermain } \\
\text { gitar } \\
\text { - klien sudah mampu melatih } \\
\quad \text { bergambar } \\
\text { A: Gangguan konsep diri : } \\
\text { Harga Diri Renda (+) } \\
\text { P : } \\
\text { - Latih kemampuan yang dipili } \\
2 \text { (3x/hari) } \\
\text { Latih kemampuan yang } \\
\text { dipilih } 3 \text { ( } 3 x / \text { hari) }\end{array}$ \\
\hline
\end{tabular}




\begin{tabular}{|c|c|c|}
\hline & dipilih 3 & \\
\hline $\begin{array}{l}\text { Selasa, } 15 \\
\text { febuari } \\
2022 \\
15.00\end{array}$ & $\begin{array}{l}\text { 1. Data } \\
\text { Tanda dan gejala: } \\
\text { Klien tampak murung dan } \\
\text { tidak bisa mempertahankan } \\
\text { kontak mata dengan perawat, } \\
\text { klien tampak lebih banyak } \\
\text { diam, nada bicara pelan } \\
\text { 2. Diagnosa keperawatan : } \\
\text { Gangguan konsep diri : } \\
\text { Harga Diri Rendah } \\
\text { 3. Tindakan keperawatan } \\
\text { SP 4: Melatih kemampuan } \\
\text { sesuai kemampuan yang } \\
\text { dipilih } 3 \\
\text { 4. RTL } \\
\text { Gangguan konsep diri : } \\
\text { Harga diri rendah Follow up } \\
\text { dan evaluasi Sp 1-4 Harga } \\
\text { diri rendah }\end{array}$ & $\begin{array}{l}\text { P : } \\
\text { - Latihan mengidentifikasi } \\
\text { kemampuan dan aspek } \\
\text { postif yang dimiliki } \\
\text { sebanyak 3x/hari } \\
\text { - Latihan menilai kemampuan } \\
\text { yang dapat digunakan } \\
\text { 3x/hari } \\
\text { - Latihan } \\
\text { menetapkan/memilki } \\
\text { kegiatan sesuai kemampuan } \\
\text { 3x/hari } \\
\text { - Melatih kemampuan sesuai } \\
\text { kemampuan yang dipilih } 1 \\
\text { 3x/hari } \\
\text { - Latih kemampuan yang } \\
\text { dipili } 2 \text { (3x/hari) } \\
\text { dipilih } 3 \text { (3x/hari) }\end{array}$ \\
\hline
\end{tabular}




\section{BAB 4 \\ PEMBAHASAN}

Setelah penulis melaksanakan asuhan keperawatan kepada Tn.I dengan gangguan sensori persepsi: halusinasi pendengaran di di Rumah Sakit Jiwa Prof. Dr. Muhammad Ildrem, maka penulis pada $\mathrm{BAB}$ ini akanmembahas kesenjangan antara teoritis dengan tinjauan kasus. Pembahasan dimulai melalui tahapan proses keperawatan yaitu pengkajian, diagnosa keparawatan, perencanaan, pelaksanaan dan evaluasi.

\subsection{Pengkajian}

Selama pengkajian dilakukan pengumpulan data bersumber dari pasien dan pengawai Rumah Sakit Jiwa. Mahasiswa mendapat sedikit kesulitan dalam menyimpulkan data kerena keluarga pasien jarang mengunjungi pasien di RS. Jiwa. Prof. Dr. Muhammad Ildrem. Maka mahasiwa melakukan pendekatan pada pasien melalui komunikasi terpeutik untuk memecahkan permasalah pasien dan juga melakukan observasi kepada pasien. Adapan upaya tersebut yaitu :

a. Melakukan pendekatan dan membina hubungan saling percaya diri pada pasien agar pasien lebih terbuka dan lebih percaya dengan menggunakan perasaan.

b. Mengadakan pengkajian pasien dengan wawancara dan tidak menemukan kesenjangan karena di temukan hal sama seperti diteori bahwasanya Halusinasi pendengaran merupakan gangguan persepsi sensori yang paling sering dialami pasien dengan skizofrenia. Pasien dengan halusinasi pendengaran sering terlihat bercakap-cakap sendiri, dan bahkan melakukan sesuatu yang membahayakan (Barus \& Siregar, 2020)

\subsection{Diagnosa Keperawatan}

Diagnosa keperawatan yang muncul sebanyak 3 diagnosa keperawatan (Aji, 2019) yang meliputi:

1. Halusinasi pendengaran

2. Isolasi social

3. Harga diri rendah

Pada kasus Tn. I ditemukan diagnosa keperawatan yang muncul yang meliputi: halusinasi, isolasi sosial, dan harga diri rendah. Dari hal tersebut di atas dapat 
dilihat terjadi kesamaan antara teori dan kasus. Dimana semua diagnosa pada teori muncul pada kasus Tn. I

\subsection{Tahap perencanaan}

Perencanaan dalam proses keperawatan lebih dikenal dengan rencana asuhan keperawatan yang merupakan tahap selanjutnya setelah pangkajian dan penentuan diagnosa keperawatan. Intervensi yang dilakukan pada masalah keperawatan gangguan sensori persepsi: halusinasi, isolasi diri dan harga diri rendah kronik pada penelitian ini menggunakan intervensi strategi pelaksanaan (SP). Strategi pelaksanaan (SP) pada intervensi masalah keperawatan gangguan sensori persepsi: halusinasi dapat diimplementasikan secara keseluruhan kepada bapak I, hal ini didukung oleh klien telah kooperatif dalam menerima masukan/ intervensi yang diberikan oleh penulis.

\subsection{Implementasi}

Pada tahap implementasi, penulis hanya mengatasi 1 masalah keperawatan yakni: diagnosa keperawatan halusinasi. Pada diagnosa keperawatan gangguan persepsi sensori halusinasi dilakukan strategi pertemuan yaitu mengidentifikasi isi, frekuensi, waktu terjadi, perasaan, respon halusinasi. Kemudian strategi pertemuan yang dilakukan yaitu latihan mengontrol halusinasi dengan cara menghardik. Strategi pertemuan yang kedua yaitu anjurkan minum obat secara teratur, strategi pertemuan yang ke tiga yaitu latihan dengan cara bercakap-cakap pada saat aktivitas dan latihan strategi pertemuan ke empat yaitu melatih klien melakukan semua jadwal kegiatan.

\subsection{Evaluasi}

Pada tinjauan kasus evaluasi yang didapatkan adalah: Klien mampu mengontrol dan mengidentifikasi halusinasi, Klien mampu melakukan latihan bercakap-cakap dengan orang lain, Klien mampu melaksanakan jadwal yang telahdibuat bersama, Klien mampu memahami penggunaan obat yang benar. 


\section{BAB 5 \\ PENUTUP}

\subsection{Kesimpulan}

Berdasarkan uraian pada pembahasan diatas, maka penulis dapat disimpulkan bahwa:

1. Pengkajian dilakukan secara langsung pada klien dan juga dengan menjadikan status klien sebagai sumber informasi yang dapat mendukung data-data pengkajian. Selama proses pengkajian, perawat mengunakan komunikasi terapeutik serta membina hubungan saling percaya antara perawat dan klien. Pada kasus Tn.I, diperoleh bahwa klien mengalami gejala-gejala halusinasi seperti mendengar suara-suara, gelisah, sulit tidur, tampak tegang, mondarmandir, tidak dapat mempertahankan kontak mata, sedih, malu, putus asa, menarik diri, mudah marah dan lain-lain. Faktor predisposisi pada Tn.I yaitu pernah mengalami gangguan jiwa sebelumnya serta memiliki riwayat mengonsumsi alkohol dan obat terlarang.

2. Diagnosa keperawatan yang muncul pada kasus Tn.I : Halusinasi pendengaran, isolasi sosial, dan harga diri rendah kronis. Tetapi pada pelaksanaannya, penulis fokus pada masalah utama yaitu halusinasi pendengaran.

3. Perencanaan dan implementasi keperawatan disesuaikan dengan strategi pertemuan pada pasien halusinasi pendengaran dan harga diri.

4. Evaluasi diperoleh bahwa terjadi peningkatan kemampuan klien dalam mengendalikan halusinasi yang dialami serta dampak pada penurunan gejala halusinasi pendengaran yang dialami.

Selama proses pengkajian, perawat mengunakan komunikasi terapeutik dan membina hubungan saling percaya antara perawat-klien. Pada kasus Tn. I diperoleh bahwa klien mengalami gejala-gejala halusinasi seperti mendengar suara-suara bisikan, marah-marah, gelisah, sulit tidur dan evaluasi diperoleh bahwa terjadi peningkatan kemampuan klien dalam mengendalikan halusinasi yang dialami serta dampak pada penurunan gejala halusinasi pendengaran yang dialami.

\subsection{Saran}




\section{Bagi Perawat}

Diharapkan dapat menerapkan komunikasi terapeutik dalam pelaksanaan strategi pertemuan 1-4 pada klien dengan halusinasi sehingga dapat mempercepat proses pemulihan klien.

2. Bagi Institusi Pendidikan

Dapat meningkatkan bimbingan klinik kepada mahasiswa profesi ners sehingga mahasiswa semakin mampu dalam melakukan asuhan keperawatan pada pasienpasien yang mengalami halusinasi pendengaran

3. Bagi Rumah Sakit

Laporan ini diharapkan dapat menjadai acuan dan referensi dalam memberikan asuhan keperawatan pada klien dengan halusinasi pendengaran. 


\section{DAFTAR PUSTAKA}

1. Aldam, Satria Fajrullah Said, and Ice Yulia Wardani. "Efektifitas penerapan standar asuhan keperawatan jiwa generalis pada pasien skizofrenia dalam menurunkan gejala halusinasi." Jurnal Keperawatan Jiwa (JKJ): Persatuan Perawat Nasional Indonesia 7.2 (2019): 165-172.

2. Pardede, J. A. "The Effects Acceptance and Aommitment Therapy and Health Education Adherence to Symptoms, Ability to Accept and Commit to Treatment and Compliance in Hallucinations Clients Mental Hospital of Medan, North Sumatra." J Psychol Psychiatry Stud 1 (2019): 30-35.

3. Pardede, J. A. "Decreasing Hallucination Response Through Perception Stimulation Group Activity Therapy In Schizophrenia Patients." Iar Journal of Medical Sciences 1.6 (2020): 304-309.

4. Pardede, Jek Amidos. "Family Knowledge about Hallucination Related to Drinking Medication Adherence on Schizophrenia Patient." Jurnal Penelitian Perawat Profesional 2.4 (2020): 399-408.

5. Pardede, Jek Amidos, et al. "Edukasi Kepatuhan Minum Obat Untuk Mencegah Kekambuhan Orang Dengan Skizofrenia." Jurnal Abdimas Mutiara 2.2 (2021): 1-5.

6. Ali, Nur Aidaa Mohd, Faudziah Yusof, and Syazwana Aziz. "Faktor-faktor penyebab penyakit skizofrenia: satu kajian kes." Jurnal Sains Sosial: Malaysian Journal of Social Sciences 4.1 (2019): 68-79.

7. Barus, Novita Susilawati, and Deborah Siregar. "Literature Review: The Effectiveness Of Classic Music Therapy Towards Auditory Hallucination In Schizophrenia Patient [Kajian Literatur: Efektivitas Terapi Musik Klasik Terhadap Halusinasi Pendengaran Pada Pasien Skizofernia]." Nursing Current: Jurnal Keperawatan 7.2 (2020): 48-57.

8. Damaiyanti \& Iskandar. Asuhan Keperawatan Jiwa. Bandung : Refika Aditama. (2014).

9. Pardede, Jek Amidos, et al. "The Effect Of Cognitive Therapy On Changes In SelfEsteem On Schizophrenia Patients." European Journal of Molecular \& Clinical Medicine 7.11: 2020.

10. Pardede, Jek Amidos. "Beban Keluarga Berhubungan Dengan Koping Saat Merawat Pasien Halusinasi." Jurnal Ilmu Keperawatan Jiwa 3.4 (2020): 445-452.

11. Dwi Oktiviani, P031714401047. Asuhan Keperawatan Jiwa Pada Tn. K dengan masalah Gangguan Persepsi Sensori: Halusinasi Pendengaran di Ruang Rokan Rumah Sakit Jiwa Tampan. Diss. Poltekkes Kemenkes Riau, 2020.

12. Hafizuddin, D. T. M. "Asuhan Keperawatan Jiwa Pada Tn. A Dengan Masalah Halusinasi Pendengaran." (2021).

13. Hartanto, Agung Eko, Gandes Widya Hendrawati, and Esti Sugiyorini. "Pengembangan Strategi Pelaksanaan Masyarakat Terhadap Penurunan Stigma Masyarakat Pada Pasien Gangguan Jiwa." Indonesian Journal for Health Sciences 5.1 (2021): 63-68.

14. Manao, Betriz Melva, and Jek Amidos Pardede. "Beban Keluarga Berhubungan Dengan Pencegahan Kekambuhan Pasien Skizofrenia." Jurnal Keperawatan Jiwa 12.3 (2019).

15. Muhith, Abdul. Pendidikan keperawatan jiwa: Teori dan aplikasi. Penerbit Andi, (2015).

16. Pardede, J. A., et al. "AP (2021)." Asuhan keperawatan Jiwa Dengan Masalah 
Halusinasi 10.

17. Pardede, Jek Amidos, and Arya Ramadia. "The Ability to Interact With Schizophrenic Patients through Socialization Group Activity Therapy." International Journal of Health Science and Medical Research 1.1 (2021): 06-10.

18. Pardede, Jek Amidos, and Rini Andriyani Siregar. "Pendidikan Kesehatan Kepatuhan Minum Obat Terhadap Perubahan Gejala Halusinasi Pada Klienskizofrenia." Mental Health 3.1 (2016).

19. Pardede, Jek Amidos, B. A. Keliat, and I. Y. Wardani. "Pengaruh Acceptance And Commitment Therapy Dan Pendidikan Kesehatan Kepatuhan Minum Obat Terhadap Gejala, Kemampuan Berkomitmen Pada Pengobatan Dan Kepatuhan Pasien Skizofrenia." FIK UI, Depok (2013).

20. Pardede, Jek Amidos, et al. "Edukasi Kepatuhan Minum Obat Untuk Mencegah Kekambuhan Orang Dengan Skizofrenia." Jurnal Abdimas Mutiara 2.2 (2021): 1-5.

21. Pardede, Jek Amidos, et al. "Ekspresi Emosi Keluarga Dengan Frekuensi Kekambuhan Pasien Skizofrenia." Idea Nursing Journal 7.3 (2016): 53-61.

22. Sianturi, Sriana Florentina. "Aplikasi Asuhan Keperawatan Jiwa Pada Ny. H Dengan Masalah Halusinasi." (2021).

23. Sihombing, R I., et al. "Penerapan Asuhan Keperawatan Jiwa Pada Ny. L Dengan Gangguan Konsep Diri : Harga Diri Rendah.” OSF Preprints, 4 Apr. 2021. Web.

24. Yosep, I., \& Sutini, T. Buku Ajar Keperawatan Jiwa dan Advance Mental Health Nursing. (2016).

25. Pardede, Jek Amidos, Erwin Silitonga, and Gustavus Endowment H. Laia. "The Effects of Cognitive Therapy on Changes in Symptoms of Hallucinations in Schizophrenic Patients." Indian Journal of Public Health 11.10 (2020): 257.

26. Pardede, Jek Amidos, Laura Mariati Siregar, and Merius Halawa. "Beban dengan Koping Keluarga Saat Merawat Pasien Skizofrenia yang Mengalami Perilaku Kekerasan." Jurnal Kesehatan 11.2 (2020): 189-196.

27. Yuanita, Tiara. Asuhan Keperawatan Klienskizofrenia Dengan Gangguan Persepsi Halusinasi Pendengaran Di RSJD Dr. Arif Zainudin Solo Surakarta. Diss. Universitas Muhammadiyah Ponorogo, 2019. 